\title{
Influence of the Microstructure on the Degree of Sensitization of a Duplex Stainless Steel UNS S31803 Aged at $650^{\circ} \mathrm{C}$
}

\author{
Evelin Barbosa de Mélo ${ }^{\mathrm{a}}$, Rodrigo Magnabosco ${ }^{\mathrm{b}}$, Carlos de Moura Neto $^{\mathrm{a}}$

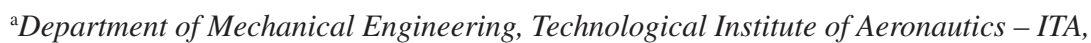 \\ Praça Marechal Eduardo Gomes, 50, CEP 12228-900, São José dos Campos, SP, Brazil \\ ${ }^{\mathrm{b}}$ Department of Materials Engineering, Ignatian Educational Foundation - FEI, \\ Av. Humberto A. C. Branco, 3972, office K5-09, CEP 09850-901, São Bernardo do Campo, SP, Brazil
}

Received: February 22, 2013; Revised: June 5, 2013

\begin{abstract}
This work evaluates the phase transformations during aging of an UNS S31803 DSS at $650^{\circ} \mathrm{C}$ and its influence on the DOS. The material was solution treated at $1175^{\circ} \mathrm{C}$ and then aged at $650^{\circ} \mathrm{C}$ for times up to $360 \mathrm{~h}$. SEM-BSC images indicate the formation of $\mathrm{Cr}_{2} \mathrm{~N}, \sigma$ and $\chi$ phases in the samples aged at $650^{\circ} \mathrm{C}$. The analysis of DL-EPR curves, obtained in a $1 \mathrm{M} \mathrm{H}_{2} \mathrm{SO}_{4}+0.25 \mathrm{M} \mathrm{NaCl}+0.01 \mathrm{M}$ $\mathrm{KSCN}$ solution, shows an increase in DOS values for samples aged at $650^{\circ} \mathrm{C}$. Probably, this increase observed in DOS values is mainly related to the presence of $\mathrm{Cr}$ - and/or Mo-depleted $\alpha$, as a result of $\sigma$ phase, $\chi$ phase and/or $\mathrm{Cr}_{2} \mathrm{~N}$ formation at $650^{\circ} \mathrm{C}$. Moreover, a possible healing up of $\mathrm{Cr}-$ and/ or Mo-depleted areas is observed between $1 \mathrm{~h}$ and $4 \mathrm{~h}$ of aging at $650^{\circ} \mathrm{C}$.
\end{abstract}

Keywords: duplex stainless steel, DL-EPR, degree of sensitization, sigma phase

\section{Introduction}

Duplex stainless steels (DSS) are those with a microstructure composed by two phases, ferrite $(\alpha)$ and austenite $(\gamma)$, which appear in approximately equal volume fractions ${ }^{1}$. Their favourable combination of properties makes this class of steels widely employed in oil and gas, petrochemical and pulp and paper industries ${ }^{2}$.

Between $-50^{\circ} \mathrm{C}$ and $250^{\circ} \mathrm{C}$, a great combination of mechanical properties and corrosion resistance is offered by DSS. However, a large variety of secondary undesirable phases may form in the temperature range of $300^{\circ} \mathrm{C}$ and $1000^{\circ} \mathrm{C}$, during isothermal aging or as a result of incorrect heat treatment procedures ${ }^{1}$.

Between $300^{\circ} \mathrm{C}$ and $1000^{\circ} \mathrm{C}$ the most important secondary phases which can precipitate are alpha prime phase $\left(\alpha^{\prime}\right)$ and $\operatorname{sigma}(\sigma)$ phase. Alpha prime phase is chromium enriched and, depending on ferrite composition, its formation may happen by nucleation and growth of precipitates or by spinodal decomposition ${ }^{3}$. Moreover, $\alpha$ ' phase formation is expected in temperatures below $500^{\circ} \mathrm{C}^{1}$, being mostly studied at $475^{\circ} \mathrm{C}$. Sigma phase is chromium and molybdenum enriched if compared to the matrix alloy ${ }^{4}$, and it is mainly formed between $650^{\circ} \mathrm{C}$ and $900^{\circ} \mathrm{C}^{5}$.

Results presented by Borba and Magnabosco ${ }^{6}$ reinforce the possibility of $\sigma$ phase formation in temperatures below $700^{\circ} \mathrm{C}$, as it is observed the formation of this phase during aging of an UNS S31803 DSS at $600^{\circ} \mathrm{C}$ and $650^{\circ} \mathrm{C}$, highly evidenced after $96 \mathrm{~h}$ of aging. Arikan and Doruk ${ }^{7}$, also working with an UNS S31803 DSS, observe the formation of $\sigma$ phase from $1000 \mathrm{~min}(\sim 16 \mathrm{~h})$ of aging at $650^{\circ} \mathrm{C}$ on, with an increase of $\sigma$ phase amount with aging time.

*e-mail: evy.barbosa@gmail.com
Between $650^{\circ} \mathrm{C}$ and $900^{\circ} \mathrm{C} \sigma$ phase may form from ferrite phase by an eutectoid decomposition mechanism leading to secondary austenite $\left(\gamma_{2}\right)$ formation $\left(\alpha \rightarrow \sigma+\gamma_{2}\right)^{1,7,8}$. However, at $850^{\circ} \mathrm{C}$, some authors ${ }^{9,10}$ found that $\sigma$ phase may form by different mechanisms depending on aging time. So, at $850^{\circ} \mathrm{C}$, for aging times up to $10 \mathrm{~min}, \sigma$ phase may form from direct precipitation from ferrite phase, resulting in $\mathrm{Cr}$ and Mo depleted $\alpha$, also denominated secondary ferrite $\left(\alpha_{2}\right)$ phase $\left(\alpha \rightarrow \sigma+\alpha_{2}\right)$. Moreover, between $30 \mathrm{~min}$ and $5 \mathrm{~h}$ of aging at $850^{\circ} \mathrm{C}$ the eutectoid decomposition of $\alpha$, resulting in $\gamma_{2}$ (also depleted in $\mathrm{Cr}$ and $\mathrm{Mo}$ ) is observed. Also, after total $\alpha$ phase consumption at $850^{\circ} \mathrm{C}, \sigma$ phase fractions continue to rise due to $\gamma$ phase consumption for its formation ${ }^{9,10}$.

Besides $\sigma$ phase formation, chi $(\chi)$ phase and chromium nitride $\left(\mathrm{Cr}_{2} \mathrm{~N}\right)$ formation may also result from isothermal heat treatments of DSS between $700^{\circ} \mathrm{C}$ and $900^{\circ} \mathrm{C}^{1}$. Usually, $\mathrm{Cr}_{2} \mathrm{~N}$ precipitation occurs intergranularly at $\alpha / \alpha$ grain boundaries or at $\alpha / \gamma$ interfaces ${ }^{1,11}$, together to the formation of $\gamma_{2}$, causing chromium depleted zones ${ }^{11}$. Chi phase formation generally occurs before $\sigma$ phase formation and is gradually consumed by $\sigma$ phase precipitation ${ }^{11-13}$. As $\chi$ phase is enriched in $\mathrm{Cr}$ and $\mathrm{Mo}$ as well as $\sigma$ phase (but with larger amounts of Mo than sigma phase ${ }^{11-14}$ ), it is expected to promote depletion of the surrounding matrix in such elements ${ }^{11}$. Besides some authors claim that $\chi$ phase formation occurs at $\alpha / \gamma$ interfaces ${ }^{13}$, other authors indicate that its formation starts at $\alpha / \alpha$ grain boundaries ${ }^{12}$.

The formation of $\mathrm{Cr}$ and Mo depleted phases such as $\alpha_{2}$ and/or $\gamma_{2}$ have a strong influence in localized corrosion resistance and such influence can be measured by the degree of sensitization (DOS) through Double-Loop Electrochemical Potentiokinetic Reactivation (DL-EPR) tests. 
Although DL-EPR tests were at first developed in order to evaluate the DOS of austenitic stainless steels ${ }^{15}$, recent studies use DL-EPR tests to evaluate the influence of isothermal aging on DSS and, consequently, of secondary phases precipitation, in the DOS of these steels ${ }^{7,16-23}$.

As far as corrosion resistance is concerned, $\sigma$ phase formation promotes an increase in the $\operatorname{DOS}^{7,16-18,20-23}$ probably as a result of etching to adjacent areas of formed $\sigma$ phase, as these regions are likely to be depleted in chromium and/ or molybdenum. Some authors, working with UNS S31803 DSS aged at $650^{\circ} \mathrm{C}$, show that, after DL-EPR tests in a $2 \mathrm{M} \mathrm{H}_{2} \mathrm{SO}_{4}+0.5 \mathrm{M} \mathrm{NaCl}+0.01 \mathrm{M} \mathrm{KSCN}$ solution, the DOS increases from 0.036236 (samples aged for $16 \mathrm{~h}$ ) to 0.824235 (samples aged for $527 \mathrm{~h})^{7}$, while others show that, after DL-EPR tests in a $0.3 \mathrm{M} \mathrm{HCl}+0.002 \mathrm{M} \mathrm{Na}_{2} \mathrm{~S}_{2} \mathrm{O}_{3}$ solution, the DOS increases from 0.075 (samples aged for $60 \mathrm{~min}$ ) to 0.2574 (samples aged for $300 \mathrm{~min})^{22}$.

Recent studies related to isothermal heat treatments of DSS at $650^{\circ} \mathrm{C}$ are mainly based upon $\sigma$ phase formation ${ }^{6,7}$; however, the possibility of $\chi$ phase formation and even of $\mathrm{Cr}_{2} \mathrm{~N}$ formation may not be neglected, as there is lack of information about such phases as far as heat treatments below $700^{\circ} \mathrm{C}$ are concerned.

Moreover, although a great number of recent works relate DSS phase transformations due to aging between $650^{\circ} \mathrm{C}$ and $900^{\circ} \mathrm{C}^{7,16-20,22-23}$ and DOS evolution, some present an incomplete microstructural analysis, mainly concerning the $\mathrm{Cr}$ and Mo depleted phases and/or areas, and fail to correlate DOS values and even DL-EPR curves features with the obtained microstructures.

Therefore, the aim of this work is to study phase transformations and its influence on the DOS of an UNS S31803 DSS aged at $650^{\circ} \mathrm{C}$.

\section{Experimental Procedures}

The studied material, UNS S31803 DSS, has the chemical composition given in Table 1 , and was received as a $3 \mathrm{~mm}$ thick sheet, rolled at $1100^{\circ} \mathrm{C}$ and cooled by forced water jet and air blast.

Solution heat treatment was conducted in the as received material for $30 \mathrm{~min}$ at $1175^{\circ} \mathrm{C}$, followed by water quenching. Then the samples were aged at $650^{\circ} \mathrm{C}$ for $20 \mathrm{~min}, 1 \mathrm{~h}, 4 \mathrm{~h}$ or $360 \mathrm{~h}$ in a tubular electric furnace which maintained aging temperature $2^{\circ} \mathrm{C}$ around the chosen temperature. All heat treatments were conducted in a $99.9 \% \mathrm{~N}_{2}$ atmosphere to suppress oxidation of the samples surfaces. Following the heat treatments samples were water quenched.

After the heat treatments the specimens were ground using silicon carbide ( $\mathrm{SiC}$ ) papers to an 80 -grit finish before mounting in thermosetting plastic, leaving an exposed surface area of approximately $0.4-0.6 \mathrm{~cm}^{2}$, parallel to the rolling direction. The mounted samples were metallographic polished in a semi-automatic grinding and polishing machine, with final polishing provided by $1-\mu \mathrm{m}$ diamond abrasive. Immediately after polishing, samples surfaces were washed with ethyl alcohol $\left(\mathrm{C}_{2} \mathrm{H}_{5} \mathrm{OH}\right)$ and dried with hot blown air.

$\mathrm{X}$-Ray diffraction, using a $\mathrm{Cu}-\mathrm{K} \alpha$ radiation, helped in phase identification. The scan was performed in the $2 \theta$ angular range of $30-120^{\circ}$ with a scan speed of $1 \%$ min and a step size of $0.04^{\circ}$.

Scanning electron microscopy (SEM), through backscattered (BSC) electron images, were also used for phase determination. BSC electron images were analysed considering that $\chi$ phase appears lighter than $\sigma$ phase due to its higher molybdenum content ${ }^{11-14}$ and that $\mathrm{Cr}_{2} \mathrm{~N}$ appear darker due to its nitrogen content ${ }^{24}$.

Quantitative metallography of $\sigma$ and $\chi$ phases (showed as a sum and denominated as intermetallic phases) was performed in six fields of each sample with an automated image analysis system attached to an optical microscope, using SEM-BSC images of polished samples. The evaluation of ferrite phase percentage was obtained by magnetic measurements using a ferritscope (FISCHER MP30) calibrated with standard samples. In each sample 20 measurements were made.

Taking into consideration only the presence of $\alpha, \gamma$ and intermetallic phases, $\gamma$ content can be calculated using Equation 1:

$\% \gamma=100-\% \alpha-\%$ intermetallic phases.

DL-EPR tests were carried out in a $1 \mathrm{M} \mathrm{H}_{2} \mathrm{SO}_{4}+0.25 \mathrm{M}$ $\mathrm{NaCl}+0.01 \mathrm{M} \mathrm{KSCN}$ solution, exposed to air, at a controlled temperature of $30^{\circ} \mathrm{C} \pm 2{ }^{\circ} \mathrm{C}$, using a jacketed glass cell as test cell. The test temperature was controlled using a thermostatic circulating water bath attached to the test cell. The test cell had a saturated calomel electrode (SCE) as a reference electrode, a platinum wire as counter electrode and, as working electrode, samples polished until $1-\mu \mathrm{m}$ diamond abrasive finish were used.

Samples were immersed in the test solution for 5 minutes to ensure both the stabilization of the open circuit potential (OCP) and the testing temperature of the cell, and then the anodic polarization was conducted from the OCP, at a scan rate of $1.67 \mathrm{mV} / \mathrm{s}$. The scan direction was reversed at the potential of $+300 \mathrm{mV}_{\mathrm{SCE}}$, and the tests were finished at the OCP previously measured. After DL-EPR tests, samples surfaces were washed with distilled water and dried with hot blown air to be examined by optical microscopy. The electrochemical tests were repeated three times for each heat-treatment condition.

The DOS was determined by the ratio between the maximum anodic current density during the reactivation $\left(i_{\mathrm{r}}\right)$ and the maximum anodic current density during the activation $\left(i_{a}\right)$, as described by Equation 2:

$\operatorname{DOS}=\mathrm{i}_{\mathrm{r}} / \mathrm{i}_{\mathrm{a}}$.

Table 1. Chemical composition (wt \%) of the studied material.

\begin{tabular}{cccccccccccccccc}
\hline $\mathbf{C r}$ & $\mathbf{N i}$ & $\mathbf{M o}$ & $\mathbf{M n}$ & $\mathbf{N}$ & $\mathbf{C}$ & $\mathbf{S i}$ & $\mathbf{C u}$ & $\mathbf{C o}$ & $\mathbf{P}$ & $\mathbf{S}$ & $\mathbf{N b}$ & $\mathbf{F e}$ \\
\hline 22.07 & 5.68 & 3.19 & 1.38 & 0.17 & 0.017 & 0.34 & 0.15 & 0.06 & 0.020 & 0.001 & 0.01 & Bal. \\
\hline
\end{tabular}




\section{Results and Discussion}

Figure 1 presents the equilibrium phase content as a function of temperature, calculated using Thermo-Calc ${ }^{\circledR}$ software and $\mathrm{TC}-\mathrm{Fe} 6$ database. At $1175^{\circ} \mathrm{C}$ (solution temperature) the equilibrium consists of $\alpha$ and $\gamma$ phases with approximate volume fractions of $62 \%$ and $38 \%$ respectively. Ferrite phase volume fraction obtained experimentally $(57.3 \pm 2.3 \%)$ is also plotted in Figure 1 and it is almost identical to the calculated equilibrium value $(62 \%)$,

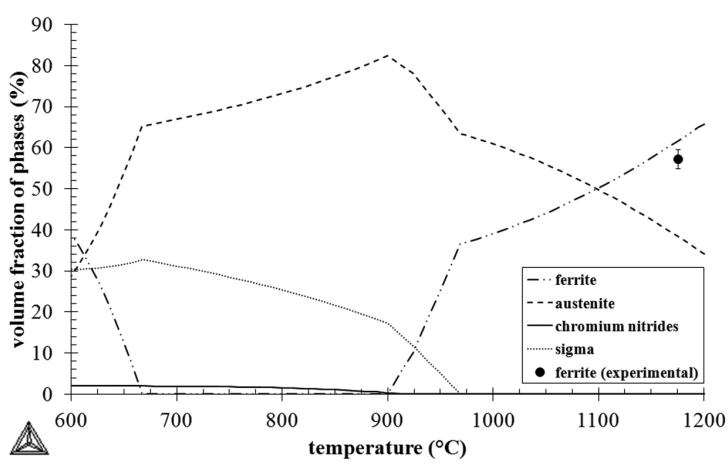

Figure 1. Equilibrium volume fraction of phases, calculated using Thermo-Calc ${ }^{\circledR}$ software and TC-Fe6 database. Ferrite phase volume fraction $(\%)$ experimental value, for the solution treated sample, is also presented.

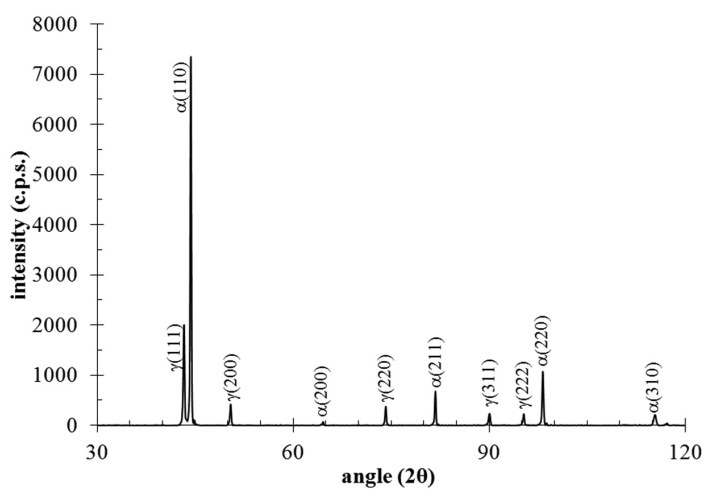

(a) considering the standard deviation of the experimental measurements. This may indicate that the solution treatment performed at $1175^{\circ} \mathrm{C}$ for $30 \mathrm{~min}$ is enough to reach equilibrium between $\alpha$ and $\gamma$ phases and to develop a duplex microstructure. Still in Figure 1 , at $650^{\circ} \mathrm{C}$, the calculated equilibrium phases are $\alpha, \gamma, \sigma$ and $\mathrm{Cr}_{2} \mathrm{~N}$, with approximate volume fractions of $12 \%, 54 \%, 32 \%$ and $2 \%$, respectively.

X-ray diffraction patterns for the UNS S31803 DSS studied are presented in Figure 2. For the solution treated sample (Figure 2a) and for the sample aged $4 \mathrm{~h}$ (Figure 2b) at $650^{\circ} \mathrm{C}$ the $\mathrm{X}$-ray diffraction patterns indicate only $\alpha$ and $\gamma$ phases, while the $\mathrm{X}$-ray diffraction pattern for the sample aged $360 \mathrm{~h}$ at $650^{\circ} \mathrm{C}$ (Figure 2c) indicates $\mathrm{Cr}_{2} \mathrm{~N}, \sigma$ and $\chi$ phases, besides $\alpha$ and $\gamma$ phases. However, as all $\mathrm{Cr}_{2} \mathrm{~N}$ and $\chi$ phase peaks appear combined with other phases peaks, this technique cannot be used to clear determine the formation of such phases.

In order to confirm the phases formed in the UNS S31803 DSS studied, SEM-BSC images were obtained (Figure 3). Solution treated sample (Figure 3a) indicates only $\alpha$ and $\gamma$ phases. For samples aged $1 \mathrm{~h}$ (Figure $3 \mathrm{~b}$ ) and $4 \mathrm{~h}$ at $650^{\circ} \mathrm{C}$ (Figure $3 \mathrm{c}$ ), besides $\alpha$ and $\gamma$ phases, $\mathrm{Cr}_{2} \mathrm{~N}$ (darker regions, due to nitrogen content ${ }^{24}$ ) formation mainly occur at $\alpha / \alpha$ phase boundaries. For the sample aged $360 \mathrm{~h}$ at $650^{\circ} \mathrm{C}$ (Figure 3d), besides $\alpha$ and $\gamma$ phases, it is also observed the presence of $\sigma$ phase (light grey, due to chromium and molybdenum contents), $\chi$ phase (white, as it is enriched in molybdenum if compared to sigma phase ${ }^{11-14}$ ) and

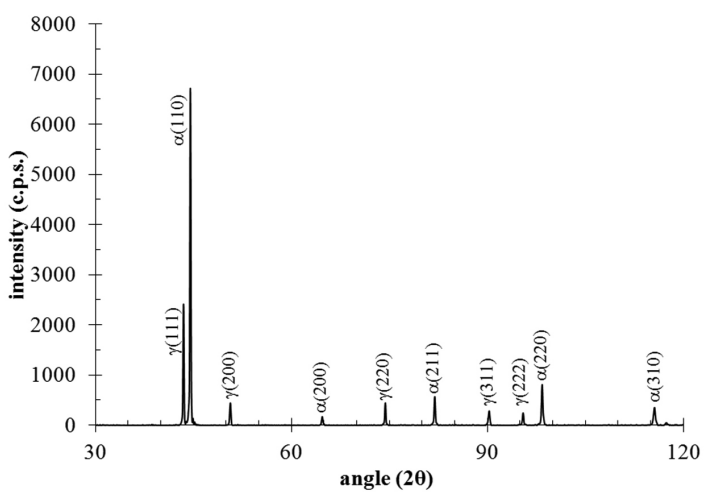

(b)

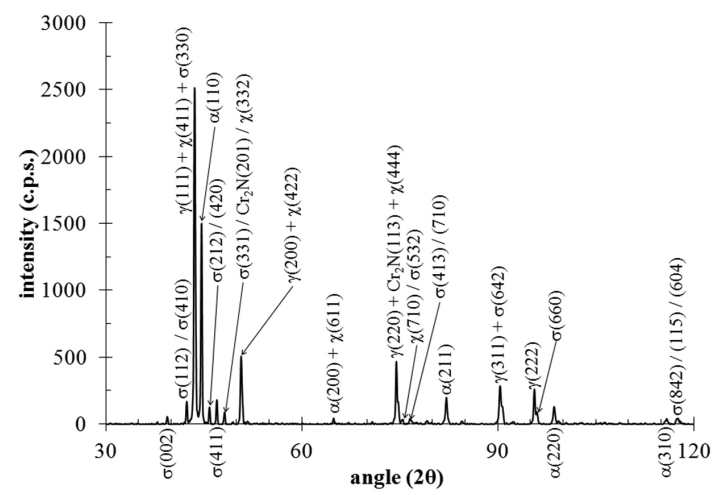

(c)

Figure 2. X-ray diffraction patterns of the UNS S31803 studied: (a) solution treated sample, (b) sample aged $4 \mathrm{~h}$ at $650^{\circ} \mathrm{C}$ and (c) sample aged $360 \mathrm{~h}$ at $650^{\circ} \mathrm{C}$. Ferrite, austenite, sigma, chi and chromium nitride peaks are represented by $\alpha, \gamma, \sigma, \chi$ and $\mathrm{Cr}_{2} \mathrm{~N}$, respectively. 


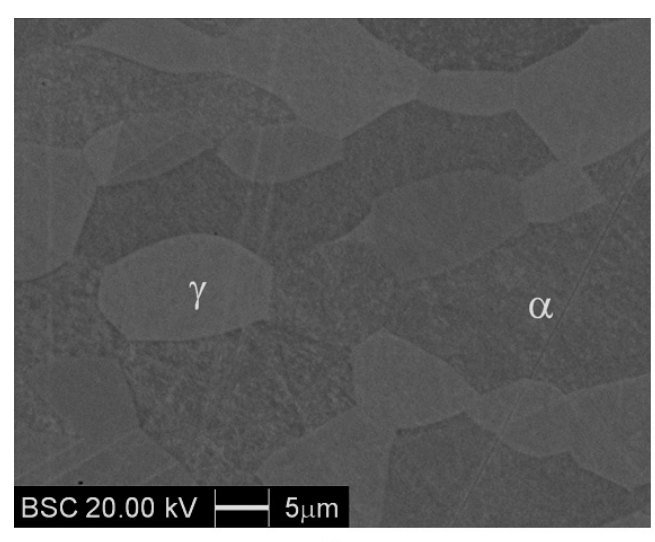

(a)

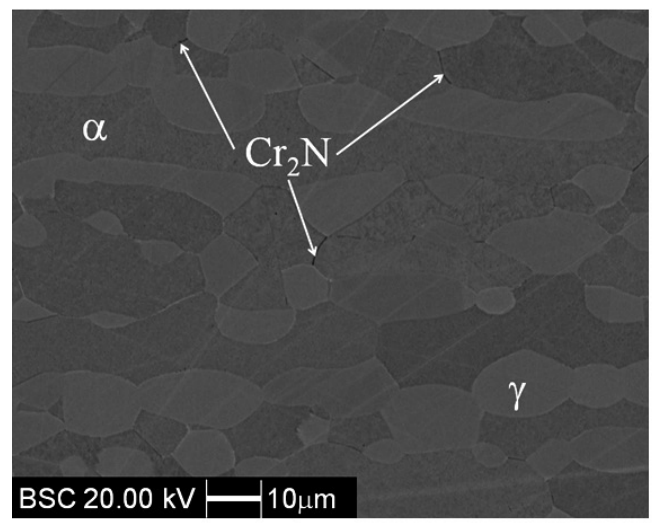

(c)

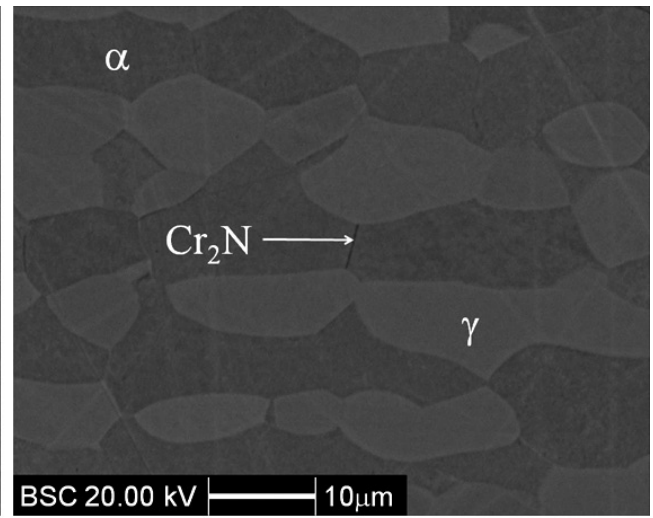

(b)

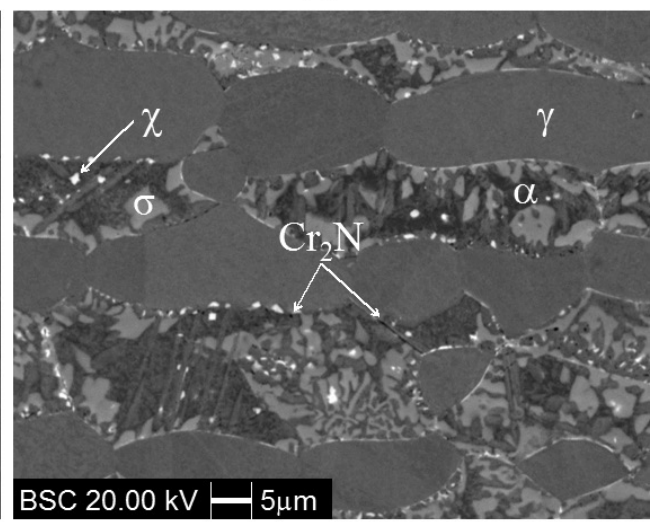

(d)

Figure 3. SEM-BSC images of: (a) solution treated sample, (b) sample aged $1 \mathrm{~h}$ at $650^{\circ} \mathrm{C}$, (c) sample aged $4 \mathrm{~h}$ at $650^{\circ} \mathrm{C}$ and (d) sample aged $360 \mathrm{~h}$ at $650^{\circ} \mathrm{C}$. Ferrite (dark grey), austenite, sigma (light grey) and chi (white) phases can be distinguished, besides the presence of chromium nitrides (dark points at grain boundaries).

$\mathrm{Cr}_{2} \mathrm{~N}$ (darker points, due to nitrogen content ${ }^{24}$ ). Therefore, BSC images confirm the evidences of $\mathrm{Cr}_{2} \mathrm{~N}$ and $\chi$ phase formation previously pointed out by $\mathrm{X}$-ray diffraction patterns (Figure 2c).

Comparing the microstructural observations of the present work with those of Arikan and Doruk ${ }^{7}$ it seems that, besides these authors make a brief comment on the possibility of $\chi$ phase or $\mathrm{Cr}_{2} \mathrm{~N}$ formation after aging an UNS S31803 DSS, they claim it was not possible to observe $\chi$ or $\mathrm{Cr}_{2} \mathrm{~N}$ in their optical micrographs. However, Arikan and Doruk $^{7}$ would have probably observed such phases if they had not performed SEM analysis in their samples after electrolytic etching with oxalic acid, as they would have prevented the $\mathrm{Cr}$ enriched phases to be etched away before SEM analysis.

It is important to point out that the absence of $\mathrm{Cr}_{2} \mathrm{~N}$ peaks in the diffraction pattern of the sample aged $4 \mathrm{~h}$ at $650^{\circ} \mathrm{C}$ (Figure 2b) may be related to the small amounts of $\mathrm{Cr}_{2} \mathrm{~N}$ observed in the BSC images (Figure 3c). So, considering the small amounts of $\mathrm{Cr}_{2} \mathrm{~N}$, their volume fraction was neglected in phase quantification, and $\sigma$ and $\chi$ phases will be designated as intermetallic phases, since they are both $\mathrm{Cr}$ and Mo-rich phases, probably associated to areas depleted in those elements.
Figure 4 shows the volume fractions of phases obtained by quantitative metallography of BSC images. For samples aged for times up to $4 \mathrm{~h}$ at $650^{\circ} \mathrm{C}$ an increase in $\gamma$ volume fraction as well as a decrease in $\alpha$ volume fraction is observed (Figure 4), but only small amounts of $\mathrm{Cr}_{2} \mathrm{~N}$ are observed mainly at $\alpha / \alpha$ phase boundaries (Figure 3 ). Intermetallic phase formation between $4 \mathrm{~h}$ and $360 \mathrm{~h}$ of aging at $650^{\circ} \mathrm{C}$ leads to a great drop in $\alpha$ phase volume fraction combined with an increase in $\gamma$ volume fraction (Figure 4). The increase in $\gamma$ volume fraction observed for samples aged up to $4 \mathrm{~h}$ at $650^{\circ} \mathrm{C}$ may be related to $\gamma_{2}$ formation in cooperation with $\mathrm{Cr}_{2} \mathrm{~N}$, while between $4 \mathrm{~h}$ and $360 \mathrm{~h}$ of aging the increase observed in $\gamma$ fraction is probably related to $\gamma_{2}$ formation as a result of $\mathrm{Cr}_{2} \mathrm{~N}, \sigma$ and $\chi$ phases formation. Moreover, the reduction observed in $\alpha$ phase fractions (Figure 4) indicates that the intermetallic phases and $\mathrm{Cr}_{2} \mathrm{~N}$ are probably formed by the consumption of $\alpha$ phase.

A comparison between the experimental volume fractions obtained after $360 \mathrm{~h}$ of aging at $650^{\circ} \mathrm{C}$ (Figure 4) and the equilibrium volume fractions (Figure 1) shows that the remaining volume fraction of $\alpha$ phase $(17.4 \pm 1.0 \%)$ is higher than expected $(12 \%)$ while the volume fraction of formed intermetallic phases $(24.3 \pm 1.1 \%)$ is lower than 
the value predicted for $\sigma$ phase at the equilibrium (32\%). Moreover, after $360 \mathrm{~h}$ of aging at $650^{\circ} \mathrm{C}$ a slightly higher volume fraction value of $\gamma$ phase $(58.3 \pm 1.5)$ is observed than the expected at equilibrium (54\%). So, it is important to highlight that as the equilibrium phases expected at $650^{\circ} \mathrm{C}$ are $\alpha, \gamma, \sigma$ and $\mathrm{Cr}_{2} \mathrm{~N}$ (Figure 1), the differences found in the comparison between experimental and calculated volume fractions of phases, as well as the presence of $\chi$ phase (Figure 3), indicate that aging at $650^{\circ} \mathrm{C}$ for time periods up to $360 \mathrm{~h}$ is not enough to establish the thermodynamic equilibrium in the UNS S31803 DSS studied.

DL-EPR tests in $1 \mathrm{M} \mathrm{H}_{2} \mathrm{SO}_{4}+0.25 \mathrm{M} \mathrm{NaCl}+0.01 \mathrm{M}$ $\mathrm{KSCN}$, for the solution treated sample and for samples aged at $650^{\circ} \mathrm{C}$, produced the typical curves presented in Figure 5.

It can be observed in Figure 5 that there is an evident increase in $\mathrm{i}_{\mathrm{a}}$ and $\mathrm{i}_{\mathrm{r}}$ for the sample aged $360 \mathrm{~h}$ at $650^{\circ} \mathrm{C}$. This increase may be related to the development of chromium and molybdenum depleted areas as a consequence of intermetallic phase formation.

Another important observation is the existence of a second current density peak during reactivation for the

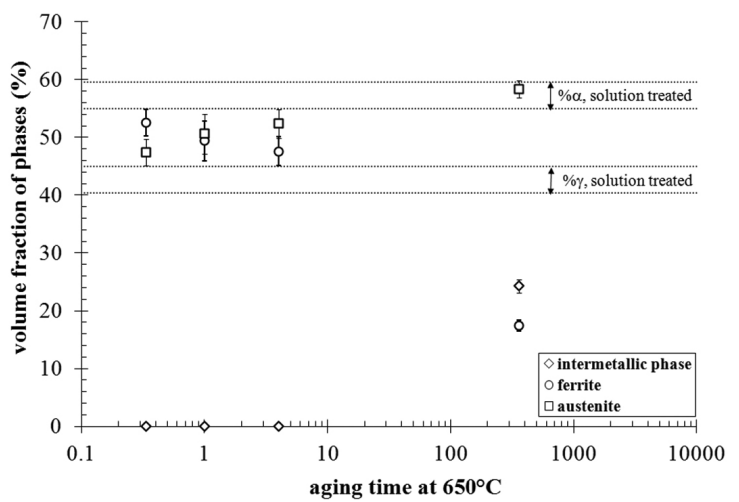

Figure 4. Volume fraction of phases as a function of aging time at $650^{\circ} \mathrm{C}$.

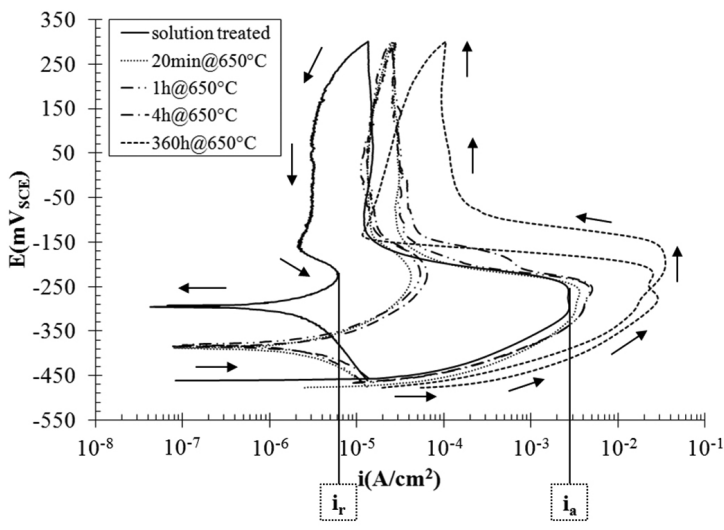

Figure 5. Typical DL-EPR curves in a $1 \mathrm{M} \mathrm{H}_{2} \mathrm{SO}_{4}+0.25 \mathrm{M}$ $\mathrm{NaCl}+0.01 \mathrm{M} \mathrm{KSCN}$ solution, for the solution treated sample and for samples aged at $650^{\circ} \mathrm{C}$. The maximum anodic current density during the reactivation $\left(\mathrm{i}_{\mathrm{r}}\right)$ and the maximum anodic current density during the activation $\left(i_{\mathrm{a}}\right.$ ) are indicated for the solution treated sample. Arrows indicate the scanning direction. sample aged $360 \mathrm{~h}$ at $650^{\circ} \mathrm{C}$. Magnabosco, Santos and Mélo ${ }^{25}$ show that the potentiodynamic polarization curves, in acid solution, for a solution treated sample of an UNS S31803 duplex stainless steel present two distinct anodic current density peaks, indicating that the one with a lower potential corresponds to $\alpha$ phase and the other with a higher potential represents $\gamma$ phase. Moreover, it is expected that a multiphase material presents an anodic polarization curve which represents a sum of the individual curves of existing phases ${ }^{26}$. So, the appearance of a second peak may be related to the existence of $\alpha$ and $\gamma$ phases, both with distinct electrochemical behaviours. Also, a high $\mathrm{Cr}$ and Mo depletion in the original $\alpha$ matrix in the sample aged $360 \mathrm{~h}$ at $650^{\circ} \mathrm{C}$ could explain why the $\alpha$ phase peak (lower potential) is highly evidenced in this sample, indicating the possibility of $\alpha_{2}$ formation.

However, it is important to point out that, as there is only one well defined peak in the activation portion of the curve, even though a second peak appears during reactivation, only the reactivation peak with higher potential was used to calculate the degree of sensitization for the sample aged for $360 \mathrm{~h}$ at $650^{\circ} \mathrm{C}$ in order to properly compare the values of $i_{r}$ and $i_{a}$.

Optical micrographs of samples surfaces after DL-EPR tests, for the solution treated sample and for the samples aged at $650^{\circ} \mathrm{C}$, are presented in Figure 6. A more intense etching at $\alpha / \alpha$ grain boundaries, $\alpha / \gamma$ interfaces and inside $\alpha$ grains is observed when the solution treated sample and the samples aged at $650^{\circ} \mathrm{C}$ are compared (Figure 6).

While the etch at $\alpha / \alpha$ grain boundaries is enhanced from $1 \mathrm{~h}$ of aging at $650^{\circ} \mathrm{C}$ on (Figure $6 \mathrm{c}$ ), at $\alpha / \gamma$ interfaces it is better observed from $4 \mathrm{~h}$ of aging at $650^{\circ} \mathrm{C}$ on (Figure $6 \mathrm{~d}$ ). Also, some areas inside $\alpha$ grains are slightly etched after $1 \mathrm{~h}$ of aging at $650^{\circ} \mathrm{C}$ and this etching becomes more intense with aging time, leading to a great material removal inside $\alpha$ grains in the sample aged $360 \mathrm{~h}$ at $650^{\circ} \mathrm{C}$.

A comparison between SEM-BSC images (Figure 3) and samples surfaces after DL-EPR tests (Figure 6) shows that etching provided by DL-EPR tests promotes material removal at intermetallic phase adjacent areas. Therefore, samples surfaces behaviour after DL-EPR tests are absolutely consistent with the microstructural observations as the material removal is probably taking place at chromium and/or molybdenum depleted areas adjacent to intermetallic phase formation. It is important to point out that $\gamma$ phase remains with no signs of etching after DL-EPR tests, reinforcing that the secondary phases formation observed are mainly related to phase transformations taking place at $\alpha$ phase.

As the analysis of the volumetric fraction of phases (Figure 4) indicates not only an increase in $\gamma$ phase fractions but also a remaining $\alpha$ phase fraction (even after aging $360 \mathrm{~h}$ at $650^{\circ} \mathrm{C}$ ), the chromium and/or molybdenum depleted areas may be related to $\alpha_{2}$ and/or $\gamma_{2}$ phases formation as a result of intermetallic phase formation. This statement is valid as it is not possible to separate the contributions of the original $\alpha$ matrix and a possible chromium and/or molybdenum $\alpha$ phase coexistence in the analysed samples.

Moreover, as the main precipitation observed for samples aged for times up to $4 \mathrm{~h}$ at $650^{\circ} \mathrm{C}$ is related to 
(a)

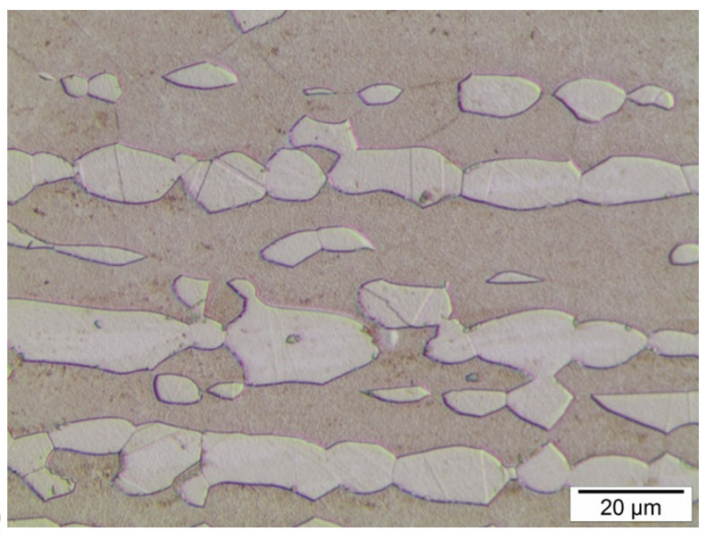

(c)

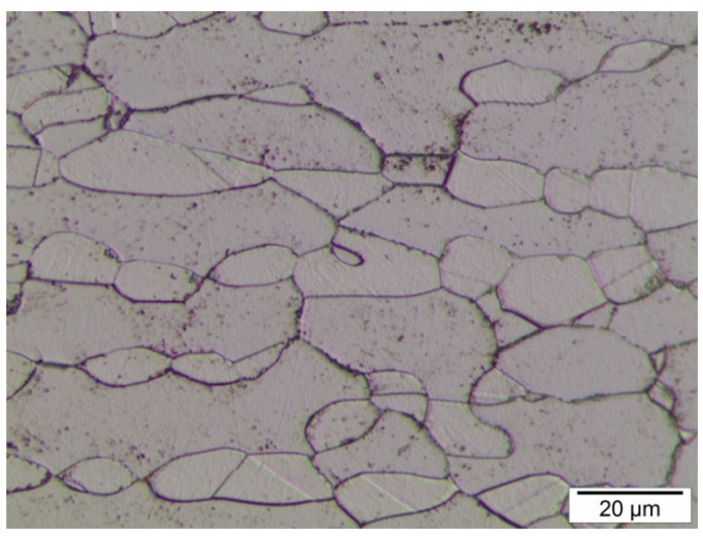

(b)

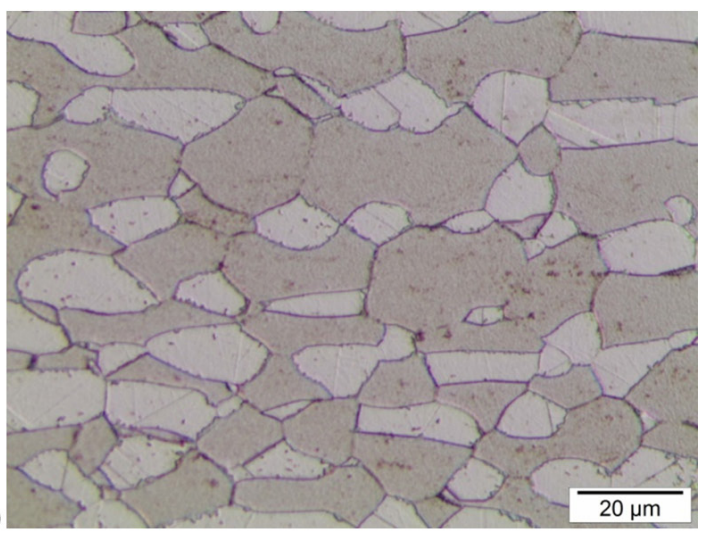

(d)

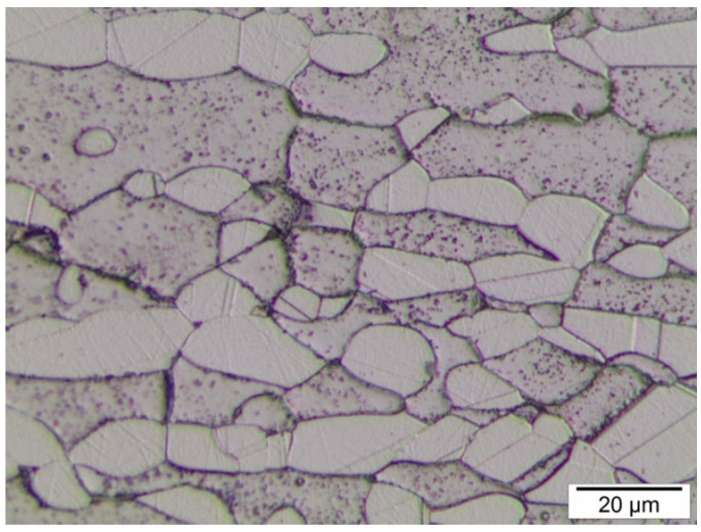

(e)

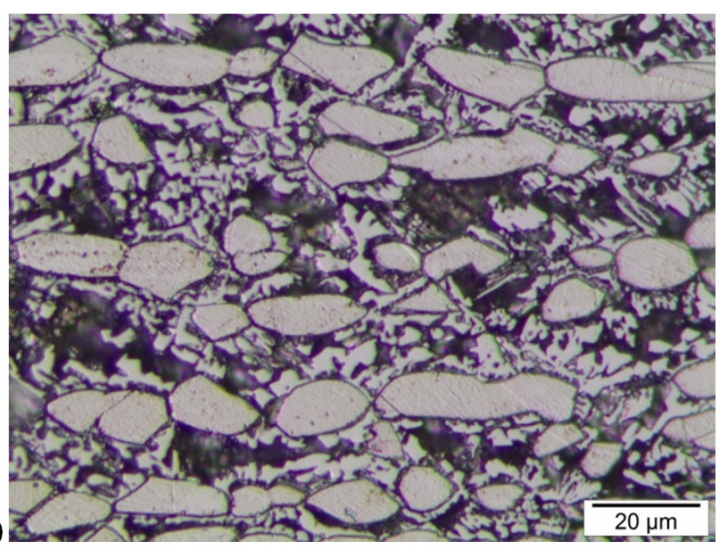

Figure 6. Optical micrographs of samples surfaces after DL-EPR tests. Solution treated sample (a) and samples aged at $650^{\circ} \mathrm{C}$ for (b) $20 \mathrm{~min}$, (c) $1 \mathrm{~h}$, (d) $4 \mathrm{~h}$ and (e) $360 \mathrm{~h}$.

$\mathrm{Cr}_{2} \mathrm{~N}$ formation, probably, for such samples, the etched areas are depleted in chromium, although the slightly etched areas observed inside ferrite grains may indicate an early stage of some secondary phase formation, presenting particles yet too small to be distinguished by SEM-BSC images. However, when the sample aged $360 \mathrm{~h}$ at $650^{\circ} \mathrm{C}$ is analysed, the etched areas may be depleted in chromium and/or molybdenum as the intermetallic phases formed are chromium and molybdenum enriched.

DOS evolution as a function of aging time at $650^{\circ} \mathrm{C}$ is compared to the solution treated sample behaviour in
Figure 7. It can be observed in Figure 7a that aged samples until $4 \mathrm{~h}$ at $650^{\circ} \mathrm{C}$ present DOS values a little higher than that of the solution treated sample, but values are still very low. However, for the sample aged for $360 \mathrm{~h}$ at $650^{\circ} \mathrm{C}$ it is observed a great increase in DOS values when compared to the solution treated sample or even other samples aged at $650^{\circ} \mathrm{C}$ (Figure 7a).

In addition, a better observation of DOS values of samples aged up to $4 \mathrm{~h}$ at $650^{\circ} \mathrm{C}$ is presented in Figure $7 \mathrm{~b}$. Besides the small increase in DOS values until $4 \mathrm{~h}$ of aging at $650^{\circ} \mathrm{C}$, when compared to the solution treated sample, 


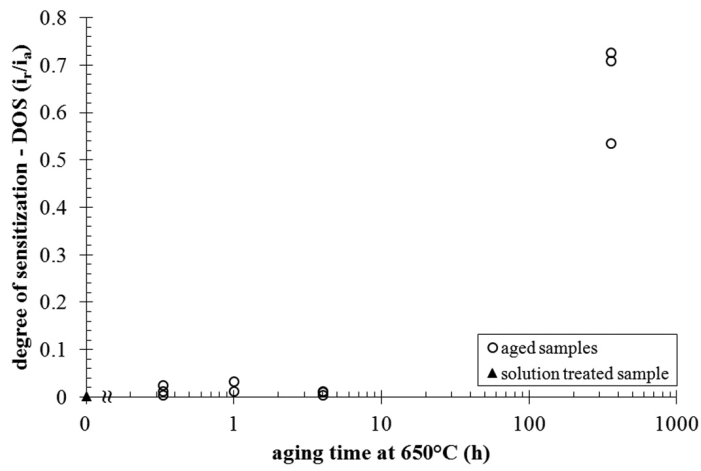

(a)

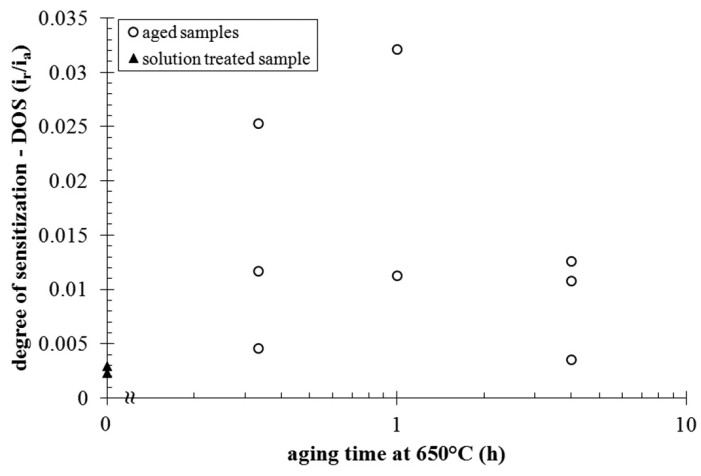

(b)

Figure 7. Degree of sensitization (DOS) in $1 \mathrm{M} \mathrm{H}_{2} \mathrm{SO}_{4}+0.25 \mathrm{M}$ $\mathrm{NaCl}+0.01 \mathrm{M} \mathrm{KSCN}$ solution for samples aged at $650^{\circ} \mathrm{C}$ compared to the solution treated sample: (a) samples aged up to $360 \mathrm{~h}$; (b) samples aged up to $4 \mathrm{~h}$.

apparently between $1 \mathrm{~h}$ and $4 \mathrm{~h}$ of aging, there is a slight reduction tendency in DOS values, already observed by other authors ${ }^{20,23,27}$. This reduction tendency in DOS values may indicate healing up of chromium/ molybdenum depleted areas due to $\mathrm{Cr}$ and Mo redistribution between the surrounding matrix and depleted areas, as stated elsewhere ${ }^{27}$. This $\mathrm{Cr}$ and Mo redistribution is more likely to happen between the surrounding matrix and depleted areas than between intermetallic phases and depleted areas as intermetallic phases do not behaviour as solid solutions when it comes to alloying elements redistribution.

In addition, the great increase observed for DOS values for the sample aged $360 \mathrm{~h}$ at $650^{\circ} \mathrm{C}$ is consistent with the observations of higher intermetallic phase fractions values for this sample, showed in Figure 4, as higher intermetallic

\section{References}

1. Nilsson JO. Super duplex stainless steels. Materials Science and Technology. 1992; 8(8):685-700.

2. Padilha AF, Plaut RL and Rios PR. Stainless steels heat treatment (chapter 12). In: Totten GE. Steel heat treatment: metallurgy and technologies. 2nd ed. Boca Raton: CRC Press; 2007. p. 695-739. phase fractions may indicate the presence of more areas subjected to $\mathrm{Cr}$ and Mo depletion. Moreover, taking into consideration that the $\gamma$ phase is not etched during DL-EPR tests and the fact that the highly evidenced $\alpha$ phase peak during reactivation (in the sample aged $360 \mathrm{~h}$ at $650^{\circ} \mathrm{C}$ ) is probably due to $\alpha_{2}$ phase formation, the main $\mathrm{Cr}-/ \mathrm{Mo}-$ depleted phase responsible for the increase in DOS values seems to be $\alpha_{2}$.

Thus, this small increase in DOS values until $4 \mathrm{~h}$ of aging, besides the slight decrease observed between $1 \mathrm{~h}$ and $4 \mathrm{~h}$ of aging, as well as the great increase for sample aged for $360 \mathrm{~h}$ at $650^{\circ} \mathrm{C}$ point out that intermetallic phase formation at $650^{\circ} \mathrm{C}$ leads to the formation of chromium and/ or molybdenum depleted regions, which are considerably deleterious to corrosion resistance of UNS S31803 duplex stainless steel studied in this work.

\section{Conclusions}

- Samples aged for times up to $4 \mathrm{~h}$ at $650^{\circ} \mathrm{C}$ mainly present $\mathrm{Cr}_{2} \mathrm{~N}$ formation at $\alpha / \alpha$ grain boundaries and a possible $\gamma_{2}$ phase formation;

- Aging at $650^{\circ} \mathrm{C}$ for times up to $360 \mathrm{~h}$ leads to $\mathrm{Cr}_{2} \mathrm{~N}$, $\chi$ and $\sigma$ phase formation probably accompanied by Cr- and/or Mo-depleted $\alpha_{2}$ and/or $\gamma_{2}$ phase formation;

- A comparison between sample surfaces after DL-EPR tests and SEM-BSC images of aged samples shows that etching provided by DL-EPR tests promotes material removal at intermetallic phase adjacent areas, indicating that the material removal is probably taking place at chromium and/or molybdenum depleted areas, which may correspond to $\alpha_{2}$ and/or $\gamma_{2}$ phases;

- A slight decrease in DOS values is observed between $1 \mathrm{~h}$ and $4 \mathrm{~h}$ of aging at $650^{\circ} \mathrm{C}$ indicating a possible healing up of the microstructure due to $\mathrm{Cr}$ and $\mathrm{Mo}$ redistribution between the surrounding matrix and depleted areas;

- The great increase observed for DOS values for the sample aged $360 \mathrm{~h}$ at $650^{\circ} \mathrm{C}$ may be associated with the existence of more areas subjected to $\mathrm{Cr}-/ \mathrm{Mo}-$ depletion as a consequence of higher intermetallic phase fractions values observed for this sample. Also, there is evidence that the main $\mathrm{Cr}$-/ Mo-depleted phase responsible for the increase in DOS values is $\alpha_{2}$.

\section{Acknowledgements}

The authors would like to thank the Brazilian National Council of Scientific and Technological Development - CNPq (Process no 141097/2011-6) for the given financial support.

3. Solomon HD and Devine TM Jr. Duplex stainless steels: a tale of two phases. In: Conference of the Duplex Stainless Steels; 1982; Ohio. Ohio: ASM; 1982. p. 693-756.

4. Herbsleb G and Schaab P. Precipitation of intermetallic compounds, nitrides and carbides in AF 22 duplex steel and their influence on corrosion behavior in acids. In: Duplex stainless steels - conference proceedings; 1982; Ohio. Ohio: ASM; 1982. p.15-40. 
5. Hall EO and Algie SH. The sigma phase. Metallurgical Reviews.1966; 11:61-88.

6. Borba RM and Magnabosco R. Alterações microestruturais entre $550^{\circ} \mathrm{C}$ e $650^{\circ} \mathrm{C}$ para o aço UNS S31803 (SAF 2205). In: Anais do IX Seminário Brasileiro do Aço Inoxidável; 2008; São Paulo. São Paulo: ABINOX; 2008. p. 30-35.

7. Arikan ME and Doruk M. Determination of Susceptibility to Intergranular Corrosion of UNS 31803 Type Duplex Stainless Steel by Electrochemical Reactivation Method. Turkish Journal of Engineering and Environmental Sciences. 2008; 32:323-335.

8. Barbosa CA, Mori FY, Souza MHC and Falleiros IGS. Formação de Fase Sigma em Aço Inoxidável Austenítico Ferrítico. Metalurgia-ABM. 1976; 32(227):669-673.

9. Magnabosco R and Alonso-Falleiros N. Pit Morphology and its Relation to Microstructure of $850^{\circ} \mathrm{C}$ Aged Duplex Stainless Steel. Corrosion. 2005; 61(2):130-136. http://dx.doi. org/10.5006/1.3278167

10. Magnabosco R and Alonso-Falleiros N. Sigma Phase Formation and Polarization Response of UNS S31803 in Sulfuric Acid. Corrosion. 2005; 61(8):807-814. http://dx.doi. org/10.5006/1.3278215

11. Nilsson JO and Wilson A. Influence of isothermal phase transformations on toughness and pitting corrosion of super duplex stainless steel SAF 2507. Materials Science and Technology. 1993; 9:545-554. http://dx.doi. org/10.1179/026708393790172222

12. Escriba DM, Materna-Morris E, Plauta RL and Padilha AF. Chi-phase precipitation in a duplex stainless steel. Materials Characterization. 2009; 60:1214-1219. http://dx.doi. org/10.1016/j.matchar.2009.04.013

13. Calliari I, Zanesco M and Ramous E. Influence of isothermal aging on secondary phases precipitation and toughness of a duplex stainless steel SAF 2205. Journal of Materials Science. 2006; 41:7643-7649. http://dx.doi.org/10.1007/ s10853-006-0857-2

14. Michalska J and Sozańska M. Qualitative and quantitative analysis of $\sigma$ and $\chi$ phases in 2205 duplex stainless steel. Materials Characterization. 2006; 56:355-362. http://dx.doi. org/10.1016/j.matchar.2005.11.003

15. Majidi AP and Streicher MA. The double loop reactivation method for detecting sensitization in AISI 304 stainless steels. Corrosion. 1984; 40(11):584-593. http://dx.doi. org/10.5006/1.3581921

16. Lopez N, Cid M, Puiggali M, Azkarate I and Pelayo A. Application of double loop electrochemical potentiodynamic reactivation test to austenitic and duplex stainless steels. Materials Science and Engineering A. 1997; 229:123-128. http://dx.doi.org/10.1016/S0921-5093(97)00008-7

17. Lopez N, Cid M and Puiggali M. Influence of $\sigma$-phase on mechanical properties and corrosion resistance of duplex stainless steels. Corrosion Science. 1999; 41:1615-1631. http:// dx.doi.org/10.1016/S0010-938X(99)00009-8
18. Chaves R and Wolynec S. Investigação da corrosão seletiva do aço inoxidável dúplex UNS S31803 por meio de ensaios de reativação potenciocinética de ciclo duplo. In: Anais do $58^{\circ}$ Congresso Anual da ABM; 2003; Rio de Janeiro. São Paulo: ABM; 2003. p. 527-536.

19. Amadou T, Braham C and Sidhom H. Double loop electrochemical potentiokinetic reactivation test optimization in checking of duplex stainless steel intergranular corrosion susceptibility. Metallurgical and Materials Transactions A. 2004; 35A:3499-3513.

20. Gong J, Jiang YM, Deng B, Xu JL, Hu JP and Li J. Evaluation of intergranular corrosion susceptibility of UNS S31803 duplex stainless steel with an optimized double loop electrochemical potentiokinetic reactivation method. Electrochimica Acta. 2010; 55:5077-5083. http://dx.doi. org/10.1016/j.electacta.2010.03.086

21. Chandra K, Singhal R, Kain V and Raja VS. Low temperature embrittlement of duplex stainless steel: Correlation between mechanical and electrochemical behavior. Materials Science and Engineering A. 2010; 527:3904-3912. http://dx.doi. org/10.1016/j.msea.2010.02.069

22. Ebrahimi N, Momeni M, Moyaed MH and Davoodi A. Correlation between critical pitting temperature and degree of sensitization on alloy 2205 duplex stainless steel. Corrosion Science. 2011; 53:637-644. http://dx.doi.org/10.1016/j. corsci.2010.10.009

23. Morais LC, Santos DC and Magnabosco R. Estudo exploratório do grau de sensitização do aço inoxidável UNS S31803 através de técnica de reativação potenciodinâmica de duplo loop. In: Anais do $67^{\circ}$ Congresso Internacional Anual da ABM; 2012; Rio de Janeiro. São Paulo: ABM; 2012.

24. Magnabosco R. Kinetics of sigma phase formation in a duplex stainless steel. Materials Research. 2009; 12(3):321-327. http:// dx.doi.org/10.1590/S1516-14392009000300012

25. Magnabosco R, Santos DC and Melo EB. Relation between microstruture and selective corrosion of duplex stainless steel submitted to heated hydrochloric acid. In: Proceedings of EUROCORR 2009; 2009; Nice. Paris: CEFRACOR, 2009.

26. West JM. Electrodeposition and Corrosion Processes. 2nd ed. London: Van Nostrand; 1970. p. 86-105.

27. Park CJ, Rao VS and Kwon HS. Effects of sigma phase on the initiation and propagation of pitting corrosion of duplex stainless steel. Corrosion. 2005; 61(1):76-83. http://dx.doi. org/10.5006/1.3278163 